\title{
Hong Kong and Singapore 1999
}

\author{
By Toh, Hai Leong \\ Spring 1999 Issue of KINEMA
}

\section{HONG KONG AND SINGAPORE INTERNATIONAL FILM FESTIVALS}

The $23^{\text {rd }}$ Hongkong International Film Festival, (31 ${ }^{\text {st }}$ March to $15^{\text {th }}$ April), focussed on a few interesting and topical issues, the most pervasive being the feeling of alienation and loneliness. The recent Balkan conflicts found their reflection in the festival as well, especially in the nonconformist Greek film-maker Theo Angelopoulos' Balkan Trilogy, a sweeping fresco including the 1991 Suspended Step of the Stork, the 1995 Ulysses' Gaze, and culminating in the sublime Eternity and a Day (Mia eoniotita ke mia mera, 1998). The reverberation of the painful Kosovo conflict is most noticeable in the Eternity, where the artist brings home the reality of the Serbs' ethnic cleansing of the Muslim Albanians through the portrait of a runaway Albanian street urchin who crosses path with the film's hero, a celebrated dying writer (played by the unsurpassable Bruno Ganz).

Theo Angelopoulos' protagonist is often a wanderer in search of truth, reconciliation and atonement, or for something profound and lasting. Forever crossing borders, he travels his long, sad journey in a cold and forbidding landscape haunted by history and mythology. The bleak scenery suggests the emptiness and loneliness of films' anti-heroes, played respectively by the late Marcello Mastroianni (Stork), Harvey Keitel (Gaze) and Bruno Ganz (Eternity). Another Balkan film, The Powder Keg (directed by Serbian Goran Paskalievic) is, like Robert Altman's Short Cuts, a tale of adultery, betrayal and madness. Srdjan Dragojevic's The Wounds, tells the horrifying tale of urban youths sliding deeper and deeper into the underworld of violence, in a metaphor for the senseless Bosnia War.

The 12th Singapore International Film Festival (16 April-- 1 May), began a day after the Hong Kong Festival ended. Both events shared the seven features of the "Films on the Year 2000" category; Tsai Ming-liang's The Hole was arguably the most impressive of this group. The Taiwan-based director's most complex film to date, The Hole once again echoes the Antonionian themes of love, alienation and loneliness. A cat seems to be the only companion of the film's male protagonist (played by Lee Kang Sheng, Tsai's regular collaborator) while his female neighbour who lives below his apartment communicates through phone sex. The two characters are alienated from the world and from each other by their hemmed-in existence. They seem to be further trapped in their flats by the constant pour of heavy rain and the threat of a mysterious virus plaguing the city. The water leak in the woman's apartment may be seen as a metaphor for her womb-like existence.

This year, not only did the Hong Kong festival expand its awards to include the FIPRESCI Award, but several new sections were also added: The Age of Independents: New Asian Film and Video, was co-organised with the Hongkong Arts Centre; Born in Hong Kong comprises three short, astute documentaries: Chan Kin-kai's and Stella Lai's 93949678; and China In Sight by Wong Yuen Ling and Yvonne Lo; Hong Kong Complex by Yuen Chan; a section on Kinderfest-Filme. The Zone Films Section included the most powerful misogynic French film to date, I Stand Alone (Seul contre tous, 1998), about a butcher whose slide into uncontrollable rage is harrowing to watch. In contrast, the Indian film, Sivan's A Journey (Oru Yatra, 1998), was a moving Ozu-like fable of a couple invited to the city to see their son. It may have moved the Jury but its Special Mention Award nevertheless went to Hong Kong's independent Nelson Yu Lik-wai's Love Will Tear Us Apart (1998) -- a raunchy tale of a Mainland Chinese girl who freelances as a prostitute while on a social visit pass. By default, it became the Festival's closing film, when Zhang Yuan's Crazy English was withdrawn at the last minute.

Singapore's Opening Gala, Ann Hui's Ordinary Heroes, was also shared by Hong Kong. This multi-faceted film portrays a group of Hong Kong political activists in the 1970s and 1980s, dedicated to their cause but suffering from romantic delusions. Hong Kong's opener, Where A Good Man Goes (1999), was directed by the recently discovered local auteur Johnnie To. His latest world premiere is about a mobster debt-collector in Macau (played by Lau Ching-wan) and his romance with a strong-willed inn-keeper (Ruby Wong) set against the Macau's backdrop of triad violence. Another film shared by the Hong Kong and Singapore 
festivals was Erick Zonca's The Dreamlife of Angels, an insightful study of the doomed friendship between Isa, a cheerful vagabond and an introverted garment worker, Marie.

The universal theme of isolation also runs through Igor Gonopolsky's sensitive documentary on the great Russian master of montage, Sergei Eisenstein to whom the Singapore festival paid tribute this year. In his Sergei Eisenstein in Alma-Aty: 1941-1944, Gonopolsky traces the great Russian film master's lonely life through his diary entries to his wife and lover. The documentary also includes the latter's drawings and rare archival photos. A film that left a lasting impression in this year's Singapore Film Festival was the Indonesian production Kuldesak. One of the most powerful stories in this anthology about Jakarta's young urbanities is that of Andre, an aspiring rock musician from a rich home but whose bleak emotional and spiritual life causes him to form an obsession on Kurt Cobain, Nirvana's lead singer who died from drug overdose and a shotgun wound in his head.

The Personals by Taiwanese director Chen Kuo Fu depicts a cross-representation of Taipei's male population -- actor, pimp, worker, mother's boy, teenager, shoe salesman -- when a lonely female eye doctor sets herself up in a teahouse to interview men to be her husband. In her desperation, she talks to her lover's phone daily without knowing he was killed in an air-crash. His widow listens to these messages in an anger which gradually gives way to compassion. In the Sri Lankan feature Death on a Full Moon Day (1997) by Prasanna Vithanage, a blind old, man refuses to believe his son has been killed by a landmine. When he finally tries to exhume the remains of his son, he finds that tree trunks have taken over the burial ground.

The most pervasive loneliness is suffered not by mortal men but by a vampire. In this respect, Werner Herzog's Nosferatu - The Vampyre (Germany, 1979), a remake of Murnau's 1922 silent classic, is as Herzog puts it, "so human...so desperately longing for love."

In Hong Kong, Christine Choy's defence of the ethnic American-Chinese immigrants' civil rights is portrayed in her documentary From Spikes To Spindles (1976), an articulate commentary on the sorry situation of the American Chinese. Her best work is arguably the seminal documentary, Who Killed Vincent Chin?, in collaboration with Renee Tajima-Peña, which shows the various viewpoints about the racially-motivated killing of an American-Chinese engineer at a Detroit girly bar.

Experienced Japanese documentary film-maker Haneda Sumiko made a case for the aged in her sensitively crafted How To Care For The Senile (1986, Japan) which has since become an important work about the ageing population. In Akiko-- Portrait of a Dancer, she traces the footsteps of Japan's greatest dancer Akiko Kaneda whose single-minded commitment to her art destroyed her marriage. An American documentary called Dancemaster directed by Matthew Diamond focussed on another dancer Paul Taylor whose choreography is influenced by his unhappy romantic involvement. Leong Sze-wing and her father Leong Poh-chih continued with their soap-opera like documentary Riding The Tiger (1997-98). It is, by far, the most important film to document Hong Kong's post-colonial localisation policy which has prevented British expatriates from working on the island without work permits.

In Singapore, Lee Kwang-mo's semi-autobiographical Spring in My Hometown and Hur Jin-ho's Christmas in August, are both brilliant debut features by two of South Korea's New Wave film-makers. In Spring In My Hometown, set during the Korean War, two small boys, Sung-Min and Chang-Hee spy on American GIs making love with local women, until one day, they find that one of the women is the Chang-Hee's mother. Christmas in August is an elegiac portrait about the unconsummated desire of an older man (Han Suk-kyu) for a young girl. Both are deeply resonant films about the consequences of knowledge or lack of it, affecting our lives for better or worse.

One of the best films, if not the most lyrical, in the Singapore festival is the 1998 Estonian film, Georgica, directed by Sulev Keedus. Jakub, an aged missionary lives on an island used by fighter aircraft for target practice. When he takes in a mute boy, both their lives are changed. Their initial awkwardness which grows into affection are captured in one of the best, understated performances in films of the master-pupil genre. It appears that this year, both the Hong Kong and Singapore International Film Festivals have come up with an excellent selection of films which is the best reward for their tireless efforts. 


\section{Author Information}

TOH Hai Leong is a Singapore-based freelance film critic and filmmaker (Zombie Dogs, 2005) who writes for independent film publications such as Screen International and World Paper. He has covered the Hong Kong International Film Festival since 1985 and specializes in the cinemas of Hong Kong, Taiwan, China, Korea and Japan. 